Tribute

\title{
TO MEL WATKINS
}

\section{BY ELAINE COBURN}

Former Editor, Socialist Studies

Although this is not the whole truth of his life, I knew Mel Watkins only as a "happy warrior," as my family might say.

At the University of Toronto in the mid to late 1990s, I was one of many students in his packed Canadian Studies classes, where he moved from theory to current events and back with his characteristic insight and wit. As might be expected, we read Harold Innis and staples' theorists. Less self-evidently, he had a soft spot for Kim Campbell, after her short-lived stint as Prime Minister and so, we were also assigned Reading "Kim" Right, by Frank Davey, notable for its violent pink cover and media analysis of ex-PM Campbell's public image.

Quite contrary to the general public opinion at the time, Mel discussed the Quebec referendum and bid for independence that year with enormous sympathy. I remember, too, his straightforward praise for Bob Rae, after Rae's immediate condemnation of the Jacques Parizeau's racist and anti-Semitic comment about losing Quebec independence to "money and the ethnic vote." This was typical of class conversations that encompassed the news of the day and linked these concerns, in a very immediate way, with scholarly readings about Canada's place in the global political economy and the right of all peoples to self-determination -emphatically not to be confused with xenophobic nationalisms.

Enthralled with Mel's classes, I asked to substitute a normal course with a one on one reading class in my final year, not appreciating the additional labour this represents for the professor. He quickly accepted, never making me feel these additional hours of teaching were a burden, and throughout the year, we had meetings in his office, once a week. We would discuss the news, whatever readings he had assigned, and, in idler moments, giggle about the best office at University College being occupied by a large computer, of the kind once needed to churn out statistical analyses.

I do not remember everything he asked me to read, but I am certain that he was the only certified University of Toronto economist who assigned articles by V.I. Lenin. He was also the lowest paid economist at the University and he mentioned, more than once, that he was the only member of the dismal science not earning over $\$ 100,000$. His left politics had a literal price.

In happier moments, Mel would talk about inheriting some of the books that Harold Innis had once owned, made more special because Innis had jotted notes in the margins. Towards the end of the academic year, he offered unstinting support when I applied for the 
Rhodes scholarship and when I was a finalist, but did not win the award, his absolute disgust on my behalf was so heartwarming that it took away much of the sting.

Outside of classes, Mel quickly swept me up in NDP politics, memorably including fundraisers at Clayton Ruby's mansion in Rosedale -- and I later worked for the first of his two failed parliamentary campaigns, a busy office where we all believed that the riding was absolutely winnable. "Like all reasonable people," as Mel liked to say, I am certain he was the best Finance Minister that Canada never had.

Such was his charisma that my mother became involved in his first and later, second campaign for federal office, so that the admiration for Mel was something of a family affair - my father, a committed historical materialist scholar, had been impressed by his efforts to reinvent the NDP as a socialist party with Jim Laxer. And Mel always spoke about his own family, his wife Kelly, and his children, with tremendous respect and affection.

I will remember Mel's absolute principled support for self-determination, for himself, and therefore, self-evidently for Quebec, for the Dene and other Indigenous peoples, at a time when this was not a popular political and human stance. I will remember too, his generosity with the young student that I was -- and his indefatigable zest and enthusiasm for politics, even if he was rarely on the winning side.

It is existentially difficult, always, to imagine a world where a voice we have known is silenced. If our lives matter in part because of what we give to others, then Mel's was absolutely a life well-lived. I know I am one of many who feel fortunate to have known his kindness, his laughter, his wit and his principled commitment to self-determination for all peoples. 